\title{
Determination of Some Selected Heavy Metals in Water, Oreochromis niloticus and Labeobarbus intermedius Samples from Abaya and Chamo Lakes
}

\author{
Dugasa Gerenfes ${ }^{1} \quad$ Endale Teju ${ }^{2}$ \\ 1.Department of Agricultural and Nutrition Research Program, Ethiopian Institute of Agriculture Research \\ (EIAR), Kulumsa Agricultural Research Center, Assela, Ethiopia \\ 2.Department of Agricultural and Nutrition Research Program, Ethiopian Institute of Agriculture Research \\ (EIAR), Holeta Agriculture Research Centre, Addis Ababa, Ethiopia
}

\begin{abstract}
The fish organs and water was collected from three sampling sites of Lakes Chamo and Abaya. A procedure consuming $12 \mathrm{~mL}$ mixture of $\mathrm{HNO}_{3}-\mathrm{H}_{2} \mathrm{O}_{2}$ for gill, kidney, liver and 1:2.5 mL mixture of $\mathrm{HNO}_{3}-\mathrm{HCl}$ for water samples for digestion of was developed. Concentrations of six metals in water and their accumulation in the edible tissue of Tilapia (Oreochromis niloticus) and Barbus (Labeobarbus intermedius) fish species were determined using Flame Atomic Absorption Spectroscopy. The results revealed that the average heavy metal concentrations in water samples were; $\mathrm{Zn} \mathrm{0.017,} \mathrm{Cu} 0.077, \mathrm{Fe} 7.50, \mathrm{Cr} 0.033, \mathrm{Cd} 0.264$ and $\mathrm{Pb} 1.731 \mathrm{mg} / \mathrm{L}$ respectivelty. The highest concentrations of iron $(\mathrm{Fe})$ and lead $(\mathrm{Pb})$ were observed at Chamo Park and Sile sites, respectively. The average contents of heavy metals in fish samples were; $\mathrm{Zn} 0.062, \mathrm{Cu} \mathrm{0.047,} \mathrm{Fe} 2.270, \mathrm{Cr} 0.041$, $\mathrm{Cd} 0.045$ and $\mathrm{Pb} 1.78 \mathrm{mg} / \mathrm{Kg}$ in both fish species. The highest accumulations of iron $(\mathrm{Fe})$ and lead $(\mathrm{Pb})$ concentration were observed in liver and gill of Tilapia fish from Chamo Lake. There was no significant difference between the two lakes in accumulating trace metals.
\end{abstract}

Keywords: Fish variety, Heavy metals, Lakes, ANOVA

DOI: $10.7176 / \mathrm{FSQM} / 83-05$

\section{Introduction}

Metals are elements, present in chemical compounds as positive ions, or in the form of cations ( + ions) in solution. Metallic elements which have high atomic weight and density much greater (at least 5 times) than water are known as heavy metals. Heavy metals are among the most serious environmental pollutants due to their high toxicity, abundance and ease of accumulation by various plant and animal organisms. Persistent increase of heavy metals in harbor sediments can be attributed to the contribution of effluent from waste water treatment plants, industries, mining, power stations and agriculture (Guevara-Riba et al., 2004). Heavy metals are extremely persistent in the environment. They are non-biodegradable and non-thermo degradable and therefore readily accumulate to toxic levels (Guevara-Riba et al., 2004). They are released into the environment from natural as well as anthropogenic activities.

Ethiopian Rift Valley Lakes which comprises of seven principal Lakes are an important area for commercial fisheries. The Lakes are also used for recreation, irrigation and industrial purposes (Gebremariam and Pearce, 2003). Despite the growing influences from natural and anthropogenic origins, there exists a general belief that presumes absence of permanent alteration or contamination of these Lakes. However, rivers that flow into some of these Lakes are heavily loaded with contaminants of natural and anthropogenic origin such as discharges from factories and domestic sources (Gebremariam and Pearce, 2003; Guevara-Riba et al., 2004).

Heavy metals have wide environmental dispersion with the tendency to accumulate in selective tissues of the living organisms and have overall potential to be toxic even at relatively low levels of exposure. Heavy metals enter the fish through gills, skin, oral in food and water. In the fish body, the metal is transported through the blood stream and either stored, transformed or eliminated in the liver, kidney or the gills (Mozaffarian and Eric, 2006; Mwangi, 2013). At high concentration, they are dangerous because they accumulate faster in living things such as fish than they are broken down.

Fish consumption can be an important route of human exposure to a variety of heavy metals such as mercury, lead, cadmium and copper as fish is often at the top of aquatic food chain and may, therefore, concentrate large amounts of some heavy metals from the water (Mozaffarian and Eric, 2006). The consumption of contaminated fish causes acute and chronic effects to humans (Nord et al., 2004). This situation has arisen as a result of the rapid growth of population, increased urbanization and expansion of industrial activities, exploration and exploitation of natural resources, extension of irrigation and other modern agricultural practices as well as the lack of environmental regulations (FAO, 1992).

The aim of this study is to determine the concentrations of heavy metals viz. $\mathrm{Cr}, \mathrm{Cd}, \mathrm{Fe}, \mathrm{Pb}, \mathrm{Cu}$ and $\mathrm{Zn}$ in water and fish species from Chamo and Abaya Lakes. The study was necessary as a large number of people consume the fish species in this area, but there is no literature report on the levels of heavy metal concentrations 
in water, Tilapia and Barbus fish species in which can be used to show the extent of the problems in the two Rift Valley lakes. The present study focuses on the levels of selected of toxic heavy metal $(\mathrm{Zn}, \mathrm{Cu}, \mathrm{Fe}, \mathrm{Cr}, \mathrm{Cd}$ and $\mathrm{Pb})$ in two fish species; Tilapia (Oreochromis niloticus) and Barbus (Labeobarbus intermedius), and water samples collected from Abaya and Chamo Lakes, which are located in Rift Valley of Ethiopia.

\section{Objectives}

General Objective of this study was

To determine some selected heavy metals $(\mathrm{Cr}, \mathrm{Pb}, \mathrm{Cd}, \mathrm{Cu}, \mathrm{Zn}$ and $\mathrm{Fe})$ in both water and fish species of Tilapia (Oreochromis niloticus) and Barbus (Labeobarbus intermedius) from Abaya and Chamo Lakes by flame atomic absorption spectrometry (FAAS).

The specific objectives of the study were

* To determine the concentration of $\mathrm{Zn}, \mathrm{Cu}, \mathrm{Fe}, \mathrm{Cr}, \mathrm{Cd}$ and $\mathrm{Pb}$ in the water samples from Abaya and Chamo Lakes.

* To study the concentration $\mathrm{Zn}, \mathrm{Cu}, \mathrm{Fe}, \mathrm{Cr}, \mathrm{Cd}$ and $\mathrm{Pb}$ in the two fish samples Tilapia (Oreochromis niloticus) and Barbus (Labeobarbus intermedius) collected from Abaya and Chamo Lakes.

\section{Materials and Methods}

\subsection{Description of the study area}

The Abaya Chamo drainage basin is a sub basin of the Rift Valley Lakes that passes through midway in the North South direction of Nations, Nationalities and Peoples Region of Southern Ethiopia. The altitude of the region varies between 4200 meter (Mount Guge) and 1108 meter above sea level (at the outflow from the Chamo Lake). The lakes are located about $510 \mathrm{Km}$ South of Addis Ababa between $5^{0} 3$ '19" and $6^{0} 45^{\prime} 11^{\prime \prime}$ North latitude and $37^{\circ} 18^{\prime} 55^{\prime}$ "and $38^{0} 7^{\prime} 55^{\prime}$ ' East longitude. These lakes are located within the Main Ethiopian Rift Valley (MER), which extends from the Southern Afar to the Konso highland in the southern Ethiopia (Ababu, 2005).

Lake Abaya is 60 kilometers long and 20 kilometers wide, with a surface area of $1162 \mathrm{Km}^{2}$. It has a maximum depth of $13.1 \mathrm{~m}$ and is at an elevation of $1285 \mathrm{~m}$. Lake Chamo is one of the three large lakes in Ethiopia next to Lake Tana and Abaya. It is located in the Great Rift Valley Lake at an elevation of 1,235 meters. It is just to the south of Lake Abaya and the city of Arba Minch, and East of the Guge Mountains. Lake Chamo is $26 \mathrm{Km}$ long and $22 \mathrm{Km}$ wide, with a surface area of $551 \mathrm{Km}^{2}$ and a maximum depth of $10 \mathrm{~m}$. The lake climate is further characterized by high rate of evaporation (about $2300 \mathrm{~mm}$ per year on average) and the precipitation average of about $600 \mathrm{~mm}$. The area in the past has been affected by global climatic change with a shift to a decrease in precipitation peaks and with consequent impact on the lakes. Therefore, its salinity increases progressively which affects greatly the lake biota (Ababu, 2005). The two lakes have been used for transport (Lake Abaya), fishery and tourism (Lake Chamo). The lakes form aquatic ecosystem having all sources of contamination from waste deposition and leaching of soluble materials from the surrounding environment to the lakes (Ababu, 2005).

\subsection{Experimental site}

All the experimental activities of this research were carried out at Kulumsa Agricultural and Nutritional Research Laboratory (KANRL), Holeta Agricultural and Soil chemistry Laboratory (HASCL) and Agricultural and Nutritional Quality Laboratory of Addis Ababa Research Laboratory.

\subsection{Instruments and Chemicals}

\subsubsection{Instruments and Apparatus}

The instrument used was fully automated PC-controlled double-beam atomic absorption spectrometer with fast sequential operation for fast multi element air acetylene flame AA determinations. Its features have 4 lamp positions and automatic lamp selection, operated with specter Base and pro-software versions with each six hollow cathode lamps namely Cadmium, Zinc, Chromium, Cupper, Iron and Lead were used throughout the experiment. A Microprossecer based PH-EC-Meter; Model 1615 was used for the determination of water $\mathrm{pH}$ and conductivity. The common laboratory apparatus which were used during the study include different sized beakers, Erlenmeyer flasks, volumetric flasks, block digester, fume hood, icebox, spatula, measuring cylinders, plastic knife, plastic net, vinyl gloves, polyethylene bags, analytical balance, crucibles, oven, mortar and pestle.

\subsubsection{Reagents and Chemicals}

All the reagents and chemicals used in the present study were analytical grade. Deionized water was used for all preparation and dilution purposes throughout the study. Nitric acid, $\mathrm{HNO}_{3}$ (Spectrosol ${ }^{\circledR}$, England) (69\%), Potassium chloride, $\mathrm{KCl}(0.01 \mathrm{~N})$, Hydrogen peroxide, $\mathrm{H}_{2} \mathrm{O}_{2}(30 \%)$ (Spectrosol®, $\mathrm{BDH}$, England) and hydrochloric acid $\mathrm{HCl},(36 \%)$ were used for fish sample digestion. Working standards of 1000 ppm were prepared for selected heavy metals $(\mathrm{Cr}, \mathrm{Zn}, \mathrm{Cd}, \mathrm{Pb}, \mathrm{Cu}$ and $\mathrm{Fe}$ ) (Puro Graphictm calibration standards, Buck Scientific, USA). Buffer solutions of $\mathrm{pH} 4$ and 7 were used for $\mathrm{pH}$ meter calibration and potassium chloride was used for conductivity meter calibration. 


\subsection{Sample Collection}

\subsubsection{Fish sampling and drying}

The selected fish species were randomly collected with the help of local fishermen within the sampling stations by using plastic nets. The freshly collected fish varieties were two types namely Tilapia (Oreochromis neloticus) and Barbus (Labeobarbus intermedius). First the scales of the fish were removed with plastic knife and the selected body parts (gills, kidney and liver) were removed carefully and separately. At the sites, gill, kidney and liver samples were removed from different fishes of the same species and washed with the Lake water, distilled water; $\mathrm{HNO}_{3}$ containing distilled water and was combined to form a single composite sample and placed in labeled plastic bags. Immediately, the plastic bags were closed with masking tape, frozen in icebox and transported to the laboratory for drying and further treatment.

\subsubsection{Collections of water samples}

Water samples were collected from six stations of each of the two lakes (Sile 1 , Sile $_{2}$, Chamo Park $_{1}$, Chamo Park $_{2}$, $\mathrm{Kulfo}_{1}$ and $\mathrm{Kulfo}_{2}$ from Lake Chamo, Bilate ${ }_{1}$, Bilate $_{2}$, Lante Lante $_{2}$, Alge $_{1}$ and Alge $)$ in March from Chamo and Abaya Lakes. This was performed at the internal of $50 \mathrm{~cm}$ with $50 \mathrm{~m}$ distance from first point to internal part by using boat in order to get representative sample and $50 \mathrm{~cm}$ depth was considered in order to exclude the dust materials as well as oily liquids suspended above the Lake and collected in to the container (Kiflom and Tarekegn, 2015). A water sampler polyethylene bottle with 1L capacity was used to collect surface water from the three different sites. All sampling bottles were cleaned before use with detergents and rinsed with deionized water for the sampling purpose. During the sampling period the bottles were rinsed with the lake water three times and then used for collecting the samples. Finally, the freshly collected water samples were mixed together and taken as composite samples for digestion process from each lake. The collected samples were placed in icebox and transported to the laboratory for further treatment.

\subsection{Digestion Procedures of Fish and Water Samples \\ 2.5.1. Digestion procedure of fish samples}

Fish gills, kidney and liver parts were dried in an electric oven at $100-105{ }^{\circ} \mathrm{C}$ until constant weight was obtained. The samples were crushed using a clean mortar and pestle to produce powdered forms. A homogenized $0.5 \mathrm{~g}$ of each grounded fish, powder sample was weighed using analytical balance. Each of $0.5 \mathrm{~g}$ of powder sample was then transferred into a digestion flask into volume $12 \mathrm{~mL}$ of a mixture of Nitric acid (70\%, Spectrosol) and hydrogen peroxide $(35 \%$, Riedel-de Haen) prepared in a 1:1 (v/v) ratio was added. The suspended mixture was digested for one hour, until a clear solution was obtained (Larissa et al., 2011). After that, it was allowed to cool and then filtered through Whatman filter paper No.42. Finally, the filtrate so obtained was diluted to $50 \mathrm{~mL}$ in a volumetric flask with deionized water and get a side for later analysis of the heavy metals content using Flame Atomic Absorption Spectrophotometer.

\subsubsection{Digestion of Water Samples}

Digestion of water took place after composite samples were prepared from the two Lakes. First of all, mark in about $20 \mathrm{~mL}$ of the beaker was made using marker. According to the Methods developed by the United State Environmental Protection Agency (USEPA) 3005 a $50 \mathrm{~mL}$ aliquot of well mixed water samples were digested in a beaker covered with a watch glass by adding $1 \mathrm{~mL}$ of concentrated $(69-72 \%) \mathrm{HNO}_{3}$ and $2.5 \mathrm{~mL}$ of concentrated $(30 \%) \mathrm{HCl}$ and heated on a hot plate at $90{ }^{\circ} \mathrm{C}$ boiled until the solution reached up to the mark $(20$ $\mathrm{mL}$ ). Then the beaker was removed and cooled. Each of the digested water samples was filtered through Whatman filter paper No.42 in to a $100 \mathrm{~mL}$ volumetric flask and filled up to the mark with deionized water by addition of $2 \mathrm{~mL}$ of nitric acid to get a clear solution (Kiflom and Tarekegn, 2015).

\subsection{Method Validation for Metal Analysis}

\subsubsection{Preparation of stock standard solution}

Working standard solutions of lead $(\mathrm{Pb})$, iron $(\mathrm{Fe})$, copper $(\mathrm{Cu})$, chromium $(\mathrm{Cr})$, zinc $(\mathrm{Zn})$ and cadmium $(\mathrm{Cd})$ were prepared from the stock standard solutions containing $1000 \mathrm{ppm}$ of element in $2 \mathrm{~N}$ nitric acid. Calibration and measurement of elements were done by using Atomic Absorption Spectrophotometer. The calibration curves were prepared for each element individually applying linear correlation by least square method. A blank reading was also taken and necessary corrections were made during the calculation of concentration of various elements.

\subsubsection{Instrumental calibration}

Calibration curves were prepared to determine the concentration of the heavy metals in the sample solutions. Intermediate standard solution $(100 \mathrm{mg} / \mathrm{L})$ of each metal was prepared from stock standard solutions containing $1000 \mathrm{mg} / \mathrm{L}$ of $\mathrm{Cd}, \mathrm{Cr}, \mathrm{Pb}, \mathrm{Cu}, \mathrm{Zn}$ and $\mathrm{Fe}$. Appropriate working standards were prepared for each metal solution using serial dilution of the intermediate solution using extraction solution. According to the instrument operation manual to attain its better sensitivity, the working standards were then aspirated one after the other into the flame atomic absorption spectrometer and its absorbance was recorded. Calibration curves were plotted with different points for each metal standard solution using absorbance against concentrations $(\mathrm{mg} / \mathrm{L})$. Immediately after 
calibration using the standard solutions, the sample solutions were aspirated into the FAAS instrument and direct reading of the metal concentrations were recorded.

\subsection{Analytical Method Validation}

\subsubsection{Method detection limit}

Three replicate blank samples were digested following the same procedures utilized for digesting the fish and water samples. Each blank was assayed for its metal contents ( $\mathrm{Cr}, \mathrm{Cd}, \mathrm{Zn}, \mathrm{Fe}$ and $\mathrm{Pb}$ ) by FAAS. The SD of the three replicate blanks was calculated to determine the MDL (David and Terry, 2008). Method detection limit (MDL) was then calculated according to equation indicated below (David and Terry, 2008; Meseret et al., 2013).

$$
\mathrm{MDL}=\mathrm{yB}+3 \mathrm{SD}
$$

Where; $\mathrm{yB}=$ mean of the replicate blank

$$
\mathrm{SD}=\text { Standard deviation of the blank }
$$

\subsection{Recovery Test}

Recovery is one of the most commonly used techniques utilized for validation of the analytical results and evaluating how far the method is acceptable for its intended purpose. In present study due to the absence of certified reference material for fish and water in our laboratory, the validity of the digestion procedure, precision and accuracy of FAAS was assured by spiking fish and water samples with standard of known concentration. The spiked and non-spiked fish and water samples were digested following the same procedure employed in the digestion of the respective samples and analyzed in similar condition. Then the percentage recoveries of the analytes were calculated by (Kiflom and Tarekegn, 2015).

Recovery $=\frac{\mathrm{CM} \text { in the spike sample-CM in the non spike sample }}{\text { Amount added }} \times 100 \%$

Where, $\mathrm{CM}=$ concentration of metal of interest According to Harvey (2000) the acceptable ranges of percentage recovery for heavy metals analysis were within $80-120 \%$.

\subsection{Heavy Metal Analysis}

After calibration of the instrument the samples were aspirated into the FAAS instrument according to standard method (APHA, 1999). Concentrations of $\mathrm{Fe}, \mathrm{Zn}, \mathrm{Pb}, \mathrm{Cd}, \mathrm{Cu}$ and $\mathrm{Cr}$ in the extracted water and different parts of fish sample were estimated by using FAAS Agilent Technology (Model-AT-240). The concentration of Cd, Cr, $\mathrm{Zn}, \mathrm{Cu}, \mathrm{Fe}$ and $\mathrm{Pb}$ were determined in both the water and fish samples. The samples were analysed in triplicates, and the blank determinations in triplicates were also run in the same manner during the analysis.

\subsection{Statistical Analysis}

The analysis of variance ANOVA was used to examine the significance level of all parameters measured. Least Significant Difference (LSD) test was used for means comparison. The level of significance for the t-test and means comparison was at $\mathrm{p}<0.05$. The concentrations of all metals in fish and water sample were expressed in $\mathrm{mg} / \mathrm{L}$.

\section{Results and Discussion}

\subsection{Physicochemical variables of water samples}

Table 1. The mean \pm SD values of some physicochemical properties of Chamo and Abaya Lakes at the three sampling sites

\begin{tabular}{llllll}
\hline \multicolumn{5}{c}{ Physicochemical Parameters } \\
\hline Sites & pH & EC $(\boldsymbol{\mu S} / \mathbf{c m})$ & Sites & $\mathbf{p H}$ & $\mathbf{E C}(\boldsymbol{\mu S} / \mathbf{c m})$ \\
\hline Sile1 & $7.66 \pm 0.15$ & $843.67 \pm 7.02$ & Bilate1 & $7.29 \pm 0.65$ & $520.67 \pm 8.02$ \\
Sile2 & $8.23 \pm 0.29$ & $818 \pm 4.53$ & Bilate2 & $7.29 \pm 0.70$ & $485.33 \pm 10.41$ \\
Chamo park1 & $8.33 \pm 0.19$ & $781 \pm 14$ & Lante1 & $8.09 \pm 0.48$ & $488.67 \pm 6.03$ \\
Chamo park2 & $8.35 \pm 0.17$ & $795 \pm 10.02$ & Lante2 & $7.99 \pm 0.15$ & $477.00 \pm 7.00$ \\
Kulfo1 & $8.52 \pm 0.18$ & $836.33 \pm 12.86$ & Alge1 & $7.91 \pm 0.25$ & $525.67 \pm 9.61$ \\
Kulfo2 & $7.80 \pm 0.43$ & $773.67 \pm 6.03$ & Ange2 & $7.89 \pm 0.21$ & $522 \pm 12.53$ \\
\hline
\end{tabular}

The $\mathrm{pH}$ of Lake Chamo ranged from $7.66 \pm 0.15-8.52 \pm 0.18$ at the site of Sile and kulfo inlets, respectively, whereas the $\mathrm{pH}$ of Lake Abaya ranged from $7.29 \pm 0.65-8.09 \pm 0.48$ at the site of Bilate and Lante inlets, respectively. The values of $\mathrm{pH}$ has relatively decreased in the lake when compared with the value reported from previous researches done by Alemayehu (2008) $(\mathrm{pH}=8.5)$ and Elizabeth et al. (1994) (8.8) for the Lake Hawassa. These may reveal that there is a notable increment in the organic matter load of the lake system. The $\mathrm{pH}$ of the Lake is within permissible limits of (FDRE, MoWR, 2002; WHO, 2008) for drinking, recreation, agricultural and aquatic life water use (6.5-9). The $\mathrm{pH}$ values investigated in the present study are relatively low when 
compared with other lakes, which may be recognized to the decomposition of organic matter in the course of time.

Conductivity is a measure of the ability of aqueous solution to carry an electric current that depends on the presence and total concentrations of ions, their mobility, valance and on the temperature. The mean levels of electrical conductivity of both lakes were recorded by conductometry using an instrument of model 4310 . In all sampling sites the EC values of Lake Chamo ranged from $773.67 \pm 6.03$ to $843.67 \pm 7.02 \mu \mathrm{S} / \mathrm{cm}$ at the inlet of Kulfo and Sile sites, respectively; whereas the EC values of the Lake Abaya were ranged from $477 \pm 7.00$ to $525.67 \pm 9.61 \mu \mathrm{S} / \mathrm{cm}$ at Lante and Alge, sites respectively. All these values are by far below the WHO (2008) guideline value recommended for drinking purpose $(1500 \mu \mathrm{S} / \mathrm{cm})$ as well as the EPA guideline value of $(1000$ $\mu \mathrm{S} / \mathrm{cm})$. Therefore, the EC values for both lakes can be assessed under excellent classes for all livestock, poultry and irrigating purposes $(\mathrm{FAO}, 1985<1000 \mu \mathrm{S} / \mathrm{cm})$. The observed variations of these values however may be accounted for the changes in the water level as a result of high rate of evaporation and lowering of the amount of drainage water pouring into the lake. The lower values are due to direct effect of dilution by drainage water especially in areas facing the drains.

\subsection{Method of Detection Limit}

Method of detection limit is defined as the minimum concentration of analyte that can be measured. In other words, it is the lowest analyte concentration that can be distinguished from statistical variations in a blank, which usually correspond to the signal of blank three times the standard deviation of the blank ( $3 \delta$ blank, where $\delta=$ standard deviation of the blanks) (David and Terry, 2008). As shown in Table 2, the method detection limits of the investigated elements by FAAS along with their instrument detection limits are presented, respectively.

Table 2. Instrument and method detection limit

\begin{tabular}{clcc}
\hline Elements & IDL $\mathbf{~ m g} / \mathbf{L}$ & MDL of Water sample (mg/L) & MDL of Fish sample (mg/L) \\
\hline $\mathrm{Zn}$ & 0.001 & 0.003 & 0.004 \\
$\mathrm{Cu}$ & 0.003 & 0.006 & 0.007 \\
$\mathrm{Fe}$ & 0.005 & 0.010 & 0.012 \\
$\mathrm{Cr}$ & 0.006 & 0.009 & 0.008 \\
$\mathrm{Cd}$ & 0.002 & 0.004 & 0.004 \\
$\mathrm{~Pb}$ & 0.010 & 0.017 & 0.014 \\
\hline
\end{tabular}

\subsection{Calibration Curves}

Calibration curves for $\mathrm{Cr}, \mathrm{Cd}, \mathrm{Zn}, \mathrm{Pb}, \mathrm{Fe}$ and $\mathrm{Cu}$ were obtained by using suitable standard solutions prepared from stock solutions. Calibration standards for the elements analyzed were prepared in concentration ranges expected for the analytes in the samples analyzed. In addition, the calibration standards were prepared by taking into consideration the optimum working ranges of the elements. The determination coefficient $\left(\mathrm{R}^{2}\right)$ values that are closer to the absolute value of 1 indicate that there is a strong relationship between the variables being determined whereas values closer to zero $(0)$ indicate that there is no linear relationship between absorbance and concentration (Mwangi, 2013). The determination coefficients of the elements were determined using prepared standards concentration versus their corresponding absorbance.

\subsection{Recovery of the Experimental Procedure}

The procedures used in the current study were validated by spiking experiments for recovery determination which is usually helpful in the absence of certified reference material (CRM) to evaluate the accuracy of the method applied for the analyte determination. This was performed by carefully spiking the standard solution prepared, in to water and fish samples to evaluate the extent to which the standard added could be recovered after determination through sample preparation. The percent recovery was calculated after small and known amounts of the heavy metals from the stock solutions were added or spiked in to the water and fish samples to be digested and after absorbance of both spiked and non-spiked samples were read. Results were obtained through calculation. Method validation is the process of providing that analytical method is acceptable for its intended purpose. As shown in Figure 1 below, the percentage recovery for the water samples lie in the range of $85.00-$ $95.35 \%$ for Lake Chamo, 83.00 - 92.7 \% for Abaya Lake, which are within the acceptable range for each metal. 


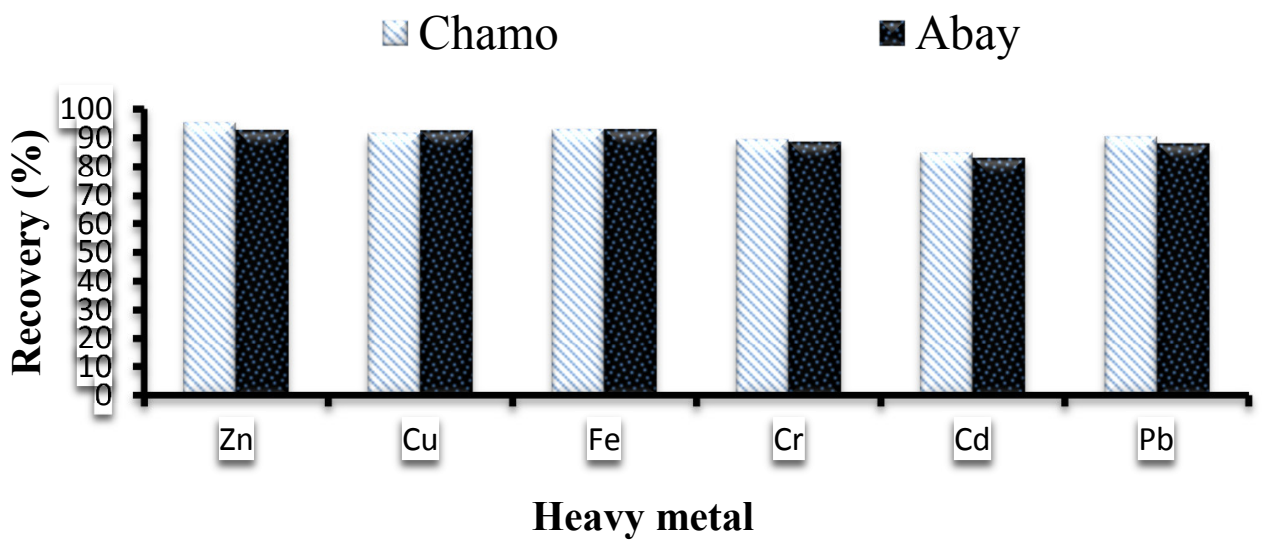

Figure 1. Percentage recovery of heavy metals in the water samples

For fish samples, the recoveries obtained from Lake Chamo varied from 87.00-98.50 and $87.00-95.50 \%$ in Tilapia and Barbus fish respectively. Although, the recoveries obtained from Lake Abaya varied from 87.00$95.50 \%$ and $88.5-93.5 \%$ in Tilapia and Barbus fish respectively. These values were within the acceptable range of 80 to $120 \%$ for the elements indicating good accuracy for the analysis procedure (Machado and Griffith, 2005).

\subsection{Evaluation of Analytical Data}

Errors in analytical results are most often expressed using accuracy and precision. The precision of an analytical procedure expresses the closeness or agreement between a series of measurements obtained from multiple sampling of the same homogeneous sample under the established conditions whereas the accuracy of an analytical procedure expresses the closeness of measurements to the true value. The precision of an analytical procedure is usually expressed as the variance, standard deviation or coefficient of variation of a series of measurements (Javed et al., 2010). In the current study the precision of the results were evaluated by the standard deviation and relative standard deviation of the results of three replicate measurements $(n=3)$. These parameters are useful in estimating indeterminate error. The results of the present analysis are reported with the corresponding standard deviation and relative standard deviation. As shown in Tables 3, the percent relative standard deviation determined was less than 10 for all samples which indicate acceptable variability of the analytical results (Javed et al., 2010).

\subsection{Levels of Heavy Metals in Water Sample}

The dissolved metal concentrations in Chamo and Abaya Lake water were measured at the six sampling sites (Sile, Chamo Park, Kulfo, Bilate, Lante and Alge) during the dry season. The concentrations of dissolved heavy metals in Chamo and Abaya lakes were found to be above the instrumental detection limit (FAAS) in all sampling sites. The average concentration $(\mathrm{mg} / \mathrm{L})$ of heavy metals in water sample from both study sites are shown in Table 3. Statistical analysis shows that the metal concentrations in the water samples differed significantly $(\mathrm{p}<0.05)$. However, there was no significance difference in each elements in water samples collected in different sampling occasions $(\mathrm{p}<0.05)$. 
Table 3. The mean \pm SD (mg/L) of heavy metal concentrations in water samples from Abaya and Chamo Lakes at three sampling sites $(\mathrm{n}=3)$

\begin{tabular}{|c|c|c|c|c|c|c|}
\hline \multicolumn{7}{|c|}{ Heavy Metals in water sample from Lake Abaya } \\
\hline Site & $\mathrm{Zn}$ & $\mathrm{Cu}$ & $\mathrm{Fe}$ & $\mathrm{Cr}$ & Cd & $\mathbf{P b}$ \\
\hline $\mathrm{B} 1$ & $0.020 \pm 0.002^{b}$ & $0.030 \pm 0.002^{\mathrm{ab}}$ & $6.474 \pm 0.185^{\mathrm{b}}$ & $0.035 \pm 0.003^{b}$ & $0.301 \pm 0.006^{\mathrm{a}}$ & $1.222 \pm 0.005^{\mathrm{a}}$ \\
\hline $\mathrm{B} 2$ & $0.024 \pm 0.001^{\mathrm{a}}$ & $0.025 \pm 0.002^{\mathrm{c}}$ & $5.939 \pm 0.039 \mathrm{c}$ & $0.018 \pm 0.002^{\mathrm{c}}$ & $0.245 \pm 0.005^{\mathrm{b}}$ & $0.923 \pm 0.026^{\mathrm{b}}$ \\
\hline L1 & $0.023 \pm 0.001^{\mathrm{a}}$ & $0.029 \pm 0.002^{\mathrm{ab}}$ & $7.094 \pm 0.355^{\mathrm{a}}$ & $0.024 \pm 0.001^{\mathrm{a}}$ & $0.240 \pm 0.002^{\mathrm{bc}}$ & $0.740 \pm 0.08^{\mathrm{c}}$ \\
\hline $\mathrm{L} 2$ & $0.016 \pm 0.001^{\mathrm{d}}$ & $0.029 \pm 0.003^{\mathrm{ab}}$ & $5.012 \pm 0.130^{\mathrm{de}}$ & $0.014 \pm 0.001^{\mathrm{d}}$ & $0.236 \pm 0.003^{\mathrm{c}}$ & $0.514 \pm 0.037^{\mathrm{d}}$ \\
\hline A1 & $0.012 \pm 0.001^{\mathrm{c}}$ & $0.023 \pm 0.002^{\mathrm{c}}$ & $4.756 \pm 0.350^{\mathrm{e}}$ & $0.015 \pm 0.001^{\mathrm{d}}$ & $0.226 \pm 0.005^{\mathrm{d}}$ & $0.347 \pm 0.030^{\mathrm{e}}$ \\
\hline $\mathrm{A} 2$ & $0.011 \pm 0.001^{\mathrm{c}}$ & $0.033 \pm 0.003^{\mathrm{a}}$ & $5.486 \pm 0.307^{\mathrm{cd}}$ & $0.026 \pm 0.002^{\mathrm{a}}$ & $0.222 \pm 0.002^{\mathrm{d}}$ & $0.294 \pm 0.003^{\mathrm{e}}$ \\
\hline LSD & 0.002 & 0.004 & 0.494 & 0.005 & 0.007 & 0.061 \\
\hline$(0.05)$ & & & & & & \\
\hline \multicolumn{7}{|c|}{ Heavy metals in water sample from Lake Chamo } \\
\hline S1 & $0.015 \pm 0.001^{\mathrm{c}}$ & $0.092 \pm 0.007^{\mathrm{b}}$ & $6.599 \pm 0.142^{b}$ & $0.024 \pm 0.002^{\mathrm{c}}$ & $0.304 \pm 0.004^{\mathrm{a}}$ & $2.367 \pm 0.167^{\mathrm{c}}$ \\
\hline $\mathrm{S} 2$ & $0.021 \pm 0.002^{\mathrm{a}}$ & $0.074 \pm 0.003^{\mathrm{c}}$ & $5.681 \pm 0.431^{\mathrm{c}}$ & $0.044 \pm 0.003^{b}$ & $0.288 \pm 0.001^{b}$ & $2.663 \pm 0.073^{b}$ \\
\hline Cpl & $0.018 \pm 0.002^{b}$ & $0.068 \pm 0.004^{\mathrm{c}}$ & $5.493 \pm 0.311^{\mathrm{c}}$ & $0.018 \pm 0.001^{\mathrm{d}}$ & $0.283 \pm 0.004^{b}$ & $2.374 \pm 0.153^{\mathrm{c}}$ \\
\hline $\mathrm{Cp} 2$ & $0.011 \pm 0.001^{\mathrm{d}}$ & $0.084 \pm 0.005^{\mathrm{b}}$ & $10.24 \pm 0.123^{\mathrm{a}}$ & $0.022 \pm 0.002^{\mathrm{c}}$ & $0.268 \pm 0.004^{\mathrm{c}}$ & $2.184 \pm 0.110^{c}$ \\
\hline $\mathrm{K} 1$ & $0.020 \pm 0.001^{\mathrm{a}}$ & $0.053 \pm 0.005^{\mathrm{d}}$ & $5.454 \pm 0.245^{\mathrm{c}}$ & $0.033 \pm 0.002^{c}$ & $0.267 \pm 0.007^{\mathrm{c}}$ & $1.770 \pm 0.015^{\mathrm{e}}$ \\
\hline $\mathrm{K} 2$ & $0.019 \pm 0.002^{\mathrm{ab}}$ & $0.051 \pm 0.005^{\mathrm{d}}$ & $6.460 \pm 0.634^{b}$ & $0.048 \pm 0.004^{b}$ & $0.254 \pm 0.002^{\mathrm{d}}$ & $1.350 \pm 0.067^{\mathrm{f}}$ \\
\hline $\begin{array}{l}\text { LSD } \\
(0,05)\end{array}$ & 0.002 & 0.010 & 0.713 & 0.010 & 0.006 & 0.126 \\
\hline $\begin{array}{l}\text { WHO, } \\
2008\end{array}$ & 5 & 1 & $5-43$ & 0.05 & 0.5 & 0.5 \\
\hline
\end{tabular}

Where; LSD- Least Significance Difference; $\mathrm{B}_{1}$ and $\mathrm{B}_{2}$-Bilate; $\mathrm{L}_{1}$ and $\mathrm{L}_{2}$-Lante; $\mathrm{A}_{1}$ and $\mathrm{A}_{2}$ - Alge; $\mathrm{S}_{1}$ and $\mathrm{S}_{2-}$ Sile; $\mathrm{CP}_{1}$ and $\mathrm{CP}_{2}-$ Chamo Park; $\mathrm{K}_{1}$ and $\mathrm{K}_{2}$ - Kulfo from Abaya and Chamo Lakes, respectively. Values are mean $\pm \mathrm{SD}$ of three sites from both lakes is analyzed individually in triplicate. Mean values in the same column followed by the same superscript letters are not significantly different $(p<0.05)$.

The concentrations of each heavy metal in both lakes were within the same range as background values for reports in literature by WHO (2008). The concentration $(\mathrm{mg} / \mathrm{L})$ of zinc in the area of investigation for lake water varies from $0.011 \pm 0.001$ to $0.021 \pm 0.002 ; 0.011 \pm 0.001$ to $0.024 \pm 0.001 \mathrm{mg} / \mathrm{L}$ from Chamo and Abaya lakes. The results show that there was no significant difference in the concentration of zinc between Sile and Kulfo site, Chamo Park and Kulfo site, but there is the significance difference between Sile and Chamo Park at $(\mathrm{P}<0.05)$. As shown in Table 3, there was no significant difference in the concentration of zinc between Alge ${ }_{1}$ and Alge $_{2}$,

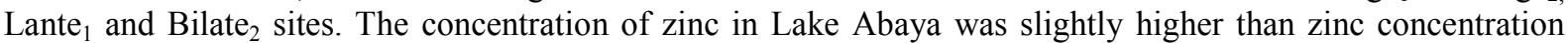
from Lake Chamo. This is may be due to the agricultural activity around the Lake Abaya was more dominated than Lake Chamo.

The level of cupper concentration in Abaya Lake was ranged from $0.023 \pm 0.002 \mathrm{mg} / \mathrm{L}$ to $0.033 \pm 0.003$; $0.051 \pm 0.005$ to $0.092 \pm 0.007 \mathrm{mg} / \mathrm{L}$ at $\mathrm{Alge}_{2}$ to the $\mathrm{Alge}_{1}$, Kulfo and Chamo Park Lake Chamo respectively. The copper concentration from Chamo Lake was higher than the concentration of copper from Abaya Lake. This is may be due to, the Lake Chamo was used for tourism and fishery, the waste from car wash and other disposal was higher than the Abaya Lake. The distributions of Fe concentration in Abaya Lake were ranged from $4.755 \pm 0.350 \mathrm{mg} / \mathrm{L}$ to $7.094 \pm 0.355 \mathrm{mg} / \mathrm{L}$ at Alge and Lante, respectively. While the concentrations of Fe from Chamo Lake were ranged from $5.454 \pm 0.245$ to $10.24 \pm 0.123 \mathrm{mg} / \mathrm{L}$ at Kulfo and Chamo Park sites. The result shows that the mean values of the iron concentration between the sampling site from Chamo and Abaya Lakes were not significantly different $(\mathrm{p}<0.05)$.

As shown in Table 3 above the level of $\mathrm{Cr}$ concentration varies from $0.014 \pm 0.001$ to $0.035 \pm 0.003 \mathrm{mg} / \mathrm{L}$ were observed in the site of Alge and Bilate from Abaya Lake, respectively. The levels of $\mathrm{Cr}$ concentration in Lake Chamo were ranged from $0.018 \pm 0.001$ to $0.048 \pm 0.004 \mathrm{mg} / \mathrm{L}$. The highest concentration of $\mathrm{Cr}$ $(0.048 \pm 0.004 \mathrm{mg} / \mathrm{L})$ was detected in the water sample from Kulfo site while the lowest concentration $(0.018 \pm 0.001 \mathrm{mg} / \mathrm{L})$ was observed from Chamo Park. The mean concentration of cadmium in the Abaya Lake varies from $0.222 \pm 0.002$ to $0.301 \pm 0.006 \mathrm{mg} / \mathrm{L}$ at the site of Alge and Bilate, respectively. The maximum level of $\mathrm{Cd}(0.301 \pm 0.006 \mathrm{mg} / \mathrm{L})$ was detected in the sample taken from Bilate site while the minimum level of $\mathrm{Cd}$ $(0.222 \pm 0.002)$ was found in the sample taken from Alge site. Although, the mean concentration of cadmium from Lake Chamo were in the range of $0.255 \pm 0.002 \mathrm{mg} / \mathrm{L}$ to $0.304 \pm 0.004 \mathrm{mg} / \mathrm{L}$ at the site of Kulfo and Sile site. The high level of $\mathrm{Cd}$ contamination may be due to soil composition, organic fertilizer and environmental pollution in the study area.

The distribution pattern of $\mathrm{Pb}$ concentration in Abaya Lake was ranged from $0.294 \pm 0.003$ to $1.222 \pm 0.005$ $\mathrm{mg} / \mathrm{L}$ at the Alge and Bilate site, respectively. Since the $\mathrm{Pb}$ concentration in Chamo Lake ranged from $1.350 \pm 0.067$ to $2.663 \pm 0.07 \mathrm{mg} / \mathrm{L}$ at the site of Kulfo and Sile site. The concentrations of lead in this study were 
above the permissible limit. This result shows that it does bring any health risk for any aquatic life and agricultural purposes. The area in the past has been affected by global climatic change with a shift to a decrease in precipitation peaks and with consequent impact on the lakes (Ababu, 2005). In previous times, those lakes are known by its fish potential as a freshwater lake, contained freshwater fish species, and now its fish potential is decreasing time to time and at the same time studies showed the water salinity increased progressively from past to present (Ababu ,2005). Generally, the distribution patterns of all heavy metals except $\mathrm{Pb}$ concentration in both lakes were below the permissible guidelines (FAO, 1985; WHO, 2004; WHO, 2008; USEPA, 2011) due to these it has no effect on the aquatic environment and human being who used these lakes.

\subsection{Levels of Heavy Metals in Tilapia and Barbus Fish}

First of all an understanding of the mechanisms or modes of action for the chemical concern is important such that the appropriate fish organs are selected and sampled. Selection of the appropriate fish organs can be specific to contaminants (Kebede et al., 2010). In the fish body, the metal is transported through the blood stream and either stored, transformed or eliminated in the liver, kidney or the gills (WHO, 2004). The levels of heavy metal concentrations recorded in the gills, kidney and livers of the two investigated fish species from the two lakes are shown in Tables 4 and 5. The mean \pm standard deviation, coefficient of variation and least significance difference of heavy metal concentration in Tilapia and Barbus fish observed from ANOVA result at $(\mathrm{p}<0.05)$.

\subsubsection{Levels of Heavy Metals in Tilapia and Barbus Fish from Chamo Lake}

The distribution and accumulation of metals in fish organs depends on the metal type, interaction with natural factors, ability to bind metals in forms that are not biologically available, character of mechanisms determining bioaccumulation of metals, and also on the type of tissue, fish species, size and age (Kebede et al., 2010). In the present study the levels zinc, copper, iron, chromium, cadmium and lead in tissues of gill, kidney and liver parts of Tilapia and Barbus fish sample collected from Abaya and Chamo Lakes were investigated.

Table 4. The heavy metal concentrations (mean \pm SD mg/kg) in Barbus and Tilapia fish from Chamo lakes $(n=3)$

\begin{tabular}{llcccccc}
\hline Fish species & Tissue & \multicolumn{7}{c}{ Heavy metals in Barbus from Abaya Lake } \\
\cline { 3 - 8 } & & Zn & Cu & Fe & Cr & Cd & Pb \\
\hline Barbus & Gill & $0.061 \pm 0.005^{\mathrm{b}}$ & $0.025 \pm 0.002^{\mathrm{b}}$ & $3.583 \pm 0.024^{\mathrm{a}}$ & $0.037 \pm 0.002^{\mathrm{a}}$ & $0.018 \pm 0.002^{\mathrm{a}}$ & $0.614 \pm 0.101^{\mathrm{a}}$ \\
Abaya Lake & Kidney & $0.076 \pm 0.001^{\mathrm{a}}$ & $0.028 \pm 0.001^{\mathrm{b}}$ & $2.735 \pm 0.015^{\mathrm{b}}$ & $0.041 \pm 0.002^{\mathrm{a}}$ & $0.017 \pm 0.001^{\mathrm{a}}$ & $0.473 \pm 0.025^{\mathrm{b}}$ \\
& Liver & $0.070 \pm 0.002^{\mathrm{a}}$ & $0.044 \pm 0.003^{\mathrm{a}}$ & $2.723 \pm 0.091^{\mathrm{b}}$ & $0.038 \pm 0.001^{\mathrm{a}}$ & $0.017 \pm 0.001^{\mathrm{a}}$ & $0.130 \pm 0.020^{\mathrm{c}}$ \\
& LSD $(0.05)$ & 0.008 & 0.006 & 0.392 & 0.004 & 0.004 & 0.051 \\
\hline Tilapia & Gill & $0.083 \pm 0.003^{\mathrm{a}}$ & $0.031 \pm 0.003^{\mathrm{b}}$ & $2.934 \pm 0.049^{\mathrm{b}}$ & $0.038 \pm 0.002^{\mathrm{a}}$ & $0.033 \pm 0.002^{\mathrm{a}}$ & $1.873 \pm 0.101^{\mathrm{a}}$ \\
Abaya Lake & Kidney & $0.047 \pm 0.002^{\mathrm{b}}$ & $0.043 \pm 0.004^{\mathrm{a}}$ & $3.628 \pm 0.162^{\mathrm{a}}$ & $0.036 \pm 0.001^{\mathrm{b}}$ & $0.033 \pm 0.002^{\mathrm{a}}$ & $1.663 \pm 0.075^{\mathrm{b}}$ \\
& Liver & $0.074 \pm 0.005^{\mathrm{c}}$ & $0.029 \pm 0.002^{\mathrm{b}}$ & $0.809 \pm 0.030^{\mathrm{c}}$ & $0.038 \pm 0.001^{\mathrm{a}}$ & $0.027 \pm 0.001^{\mathrm{b}}$ & $1.630 \pm 0.040^{\mathrm{b}}$ \\
& LSD(0.05) & 0.007 & 0.008 & 0.186 & 0.002 & 0.003 & 0.070 \\
WHO (1985) & & $10-75$ & 3.0 & 100 & 0.15 & 2.0 & 0.2 \\
FEPA (2003) & & 75 & 1.3 & 100 & 0.15 & 2.0 & 0.2 \\
\hline Whyyyyyyyy
\end{tabular}

Where; LSD-Least Significant Difference, Values are mean \pm SD of the three tissues of fish from each fish species, analyzed individually in triplicate. Mean values in the same column followed by the same superscript letters are not significantly different $(\mathrm{p}<0.05)$.

\subsubsection{Levels of Heavy Metals in Tilapia and Barbus Fish from Abaya Lake}

The distribution of metals in fish organs depends on the metal type, interaction with natural factors, ability to bind metals in forms that are not biologically available, excretion of metals, and also on the type of tissue, fish species, size and age (Kebede et al., 2010). The levels of mean values in the gills, kidney and livers of the two investigated fish species from the Abaya Lake are shown in Tables 5 below.

Table 5. The mean \pm SD (mg/Kg) heavy metal concentrations in Barbus and Tilapia fish from Abaya lakes $(\mathrm{n}=$ 3)

\begin{tabular}{|c|c|c|c|c|c|c|c|}
\hline \multirow{2}{*}{$\begin{array}{l}\text { Fish } \\
\text { species }\end{array}$} & \multirow[t]{2}{*}{ Tissue } & \multicolumn{6}{|c|}{ Heavy metals in Barbus from Abaya Lake } \\
\hline & & $\mathbf{Z n}$ & $\mathbf{C u}$ & $\mathbf{F e}$ & $\mathrm{Cr}$ & Cd & \\
\hline Barbus & Gill & $0.061 \pm 0.005^{b}$ & $0.025 \pm 0.002^{b}$ & $3.583 \pm 0.024^{\mathrm{a}}$ & $0.037 \pm 0.002^{\mathrm{a}}$ & $0.018 \pm 0.002^{\mathrm{a}}$ & $0.614 \pm 0.101^{\mathrm{a}}$ \\
\hline Abaya & Kidney & $0.076 \pm 0.001^{\mathrm{a}}$ & $0.028 \pm 0.001^{\mathrm{b}}$ & $2.735 \pm 0.015^{\mathrm{b}}$ & $0.041 \pm 0.002^{\mathrm{a}}$ & $0.017 \pm 0.001^{\mathrm{a}}$ & $0.473 \pm 0.025^{\mathrm{b}}$ \\
\hline \multirow[t]{2}{*}{ Lake } & Liver & $0.070 \pm 0.002^{\mathrm{a}}$ & $0.044 \pm 0.003^{\mathrm{a}}$ & $2.723 \pm 0.091^{\mathrm{b}}$ & $0.038 \pm 0.001^{\mathrm{a}}$ & $0.017 \pm 0.001^{\mathrm{a}}$ & $0.130 \pm 0.020^{\mathrm{c}}$ \\
\hline & $\operatorname{LSD}(0.05)$ & 0.008 & 0.006 & 0.392 & 0.004 & 0.004 & 0.051 \\
\hline \multicolumn{8}{|c|}{ Heavy metals in Tilapia from Abaya Lake } \\
\hline Tilapia & Gill & $0.083 \pm 0.003^{\mathrm{a}}$ & $0.031 \pm 0.003^{\mathrm{b}}$ & $2.934 \pm 0.049$ & $0.038 \pm 0.002^{\mathrm{a}}$ & $0.033 \pm 0.002^{\mathrm{a}}$ & $1.873 \pm 0.101^{\mathrm{a}}$ \\
\hline Abaya & Kidney & $0.047 \pm 0.002^{b}$ & $0.043 \pm 0.004^{\mathrm{a}}$ & $3.628 \pm 0.162^{2}$ & $0.036 \pm 0.001^{\mathrm{b}}$ & $0.033 \pm 0.002^{\mathrm{a}}$ & $1.663 \pm 0.075^{\mathrm{b}}$ \\
\hline \multirow[t]{2}{*}{ Lake } & Liver & $0.074 \pm 0.005^{\mathrm{c}}$ & $0.029 \pm 0.002^{b}$ & $0.809 \pm 0.030^{\complement}$ & $0.038 \pm 0.001^{\mathrm{a}}$ & $0.027 \pm 0.001^{\mathrm{b}}$ & $1.630 \pm 0.040^{\mathrm{b}}$ \\
\hline & $\operatorname{LSD}(0.05)$ & 0.007 & 0.008 & 0.186 & 0.002 & 0.003 & 0.070 \\
\hline \multicolumn{2}{|c|}{ WHO (1985) } & $10-75$ & 3.0 & 100 & 0.15 & 2.0 & 0.2 \\
\hline \multicolumn{2}{|c|}{ FEPA (2003) } & 75 & 1.3 & 100 & 0.15 & 2.0 & 0.2 \\
\hline
\end{tabular}

Where; LSD-Least Significant Difference, Values are mean \pm SD of the three tissues of fish from each fish 
species, analyzed individually in triplicate. Mean values in the same column followed by the same superscript letters are not significantly different $(\mathrm{p}<0.05)$.

As indicated in the Table above the metal concentrations in the fish species did not vary between the sampling sites and $\mathrm{Cd}, \mathrm{Zn}, \mathrm{Cr}, \mathrm{Cu}$ concentrations did not differ between fish species $(\mathrm{p}<0.05)$. However, Fe and $\mathrm{Pb}$ concentrations were highly significant $(\mathrm{p}<0.05)$ in tilapia than in barbus when the fish species are compared between Chamo and Abaya Lakes.

\subsection{T-test for sample analysis}

The mean differences between the values of samples obtained in this study were evaluated by the student's paired t-test at $95 \%$ confidence level. To find out the significance differences between the mean values of the various determination both experimental (statistical) and critical t- value were considered. The number of degrees of freedom for finding the t-value is $\left(n_{1}+n_{2}\right)-2$, where $n_{1}$ and $n_{2}$ are number of replicate measurements of sample A and sample B, respectively. The pooled standard deviation value can be obtained by:

Table 6. Mean, standard deviation, number of triplicate measurement and experimental t- values of the selected heavy metals in Chamo and Abaya Lakes

\begin{tabular}{|c|c|c|c|c|c|c|c|}
\hline Metals & Lakes & $\mathbf{n}$ & Mean & SD & t-exp. & t-crit. & Conclusion \\
\hline \multirow[t]{2}{*}{$\mathrm{Zn}$} & $\mathrm{AL}$ & 3 & 0.015 & 0.0006 & 0.0 & 2.78 & $\mathrm{H}_{\mathrm{o}}$ retained \\
\hline & $\mathrm{CL}$ & & 0.015 & 0.0001 & & & \\
\hline \multirow[t]{2}{*}{$\mathrm{Cu}$} & $\mathrm{AL}$ & 3 & 0.023 & 0.002 & 26.421 & 2.78 & $\mathrm{H}_{\mathrm{o}}$ rejected \\
\hline & $\mathrm{CL}$ & & 0.078 & 0.003 & & & \\
\hline \multirow[t]{2}{*}{$\mathrm{Fe}$} & $\mathrm{AL}$ & 3 & 5.578 & 0.153 & 3.506 & 2.78 & $\mathrm{H}_{\mathrm{o}}$ rejected \\
\hline & $\mathrm{CL}$ & & 6.353 & 0.351 & & & \\
\hline \multirow[t]{2}{*}{$\mathrm{Cr}$} & $\mathrm{AL}$ & 3 & 0.034 & 0.001 & 10.070 & 2.78 & $\mathrm{H}_{\mathrm{o}}$ rejected \\
\hline & $\mathrm{CL}$ & & 0.047 & 0.002 & & & \\
\hline \multirow[t]{2}{*}{$\mathrm{Cd}$} & $\mathrm{AL}$ & 3 & 0.263 & 0.006 & 0.743 & 2.78 & $\mathrm{H}_{\mathrm{o}}$ retained \\
\hline & $\mathrm{CL}$ & & 0.268 & 0.010 & & & \\
\hline \multirow[t]{2}{*}{$\mathrm{Pb}$} & $\mathrm{AL}$ & 3 & 0.612 & 0.024 & 34.005 & 2.78 & $\mathrm{H}_{\mathrm{o}}$ rejected \\
\hline & $\mathrm{CL}$ & & 2.233 & 0.079 & & & \\
\hline
\end{tabular}

Where; $\mathrm{AL}=$ Abaya Lake, $\mathrm{CL}=$ Chamo Lake, $\mathrm{n}=$ number of replicate measurements, $\mathrm{SD}=$ standard deviation, $\mathrm{t}$ exp. $=$ experimental t- value, $\mathrm{t}$-crit. $=$ critical $\mathrm{t}$-value.

There are 4 degrees of freedom for each heavy metal measurement and the critical value at $t_{4}=$ from table is $2.78(\mathrm{P}=0.05)$. The obtained value of $\mathrm{t}=0,0.743$ for zinc and cadmium determination was less than the critical value so the null hypothesis is retained which is to mean that there is no significant difference in concentration of zinc and cadmium between the two lakes. The calculated t- values of $26.421,3.506,10.070$ and 34.005 for copper, iron, chromium and lead are greater than the critical t-value, here also the null hypothesis is rejected that there is a significant difference $(\mathrm{p}=0.05)$ between the mean concentration with respect to copper, iron, chromium and lead between the two lakes. In a series of experiments on the determination of mean difference between selected heavy metals $(\mathrm{Zn}, \mathrm{Cu}, \mathrm{Fe}, \mathrm{Cr}, \mathrm{Cd}$ and $\mathrm{Pb})$ in Tilapia and Barbus fish samples from Chamo and Abaya Lakes were obtained from the calculation of their mean value and standard deviation. The experimental t- value of $\mathrm{Zn}$ and Fe were less than the critical t-values, this shows there is no significance difference $(\mathrm{p}=0.05)$ between the mean values in gills of both fish species collected from Chamo Lake. But, the t-values of $\mathrm{Cr}, \mathrm{Cd}$ and $\mathrm{Pb}$ were above the critical t-value, this indicates there was highly significance difference in gill of the two fish species. Although, the experimental $t$-value of copper in the kidney was not significantly different $(p=0.05)$ between the values of fish species.

\subsection{Summary and Conclusions}

The study determines heavy metals concentrations in edible part of two fish species (Oreochromis niloticus and Labeobarbus intermedius) as well as with water samples collected from Chamo and Abaya, Ethiopian Rift Valley Lakes. An efficient procedure for the digestion of the gills, kidney and liver of fish has been validated through recovery studies. Using the optimal digestion procedure, similar concentrations of trace metals in fishes (Oreochromis niloticus and Labeobarbus intermedius) from the two lakes were observed. Moreover, results revealed absence of any reliable interspecies differences in the content of trace metals in fish tissue. Furthermore, Oreochromis niloticus and Labeobarbus intermedius tend to accumulate trace metals and thus, they may be considered as useful species for monitoring pollution of lakes by trace metals. The high accumulation of $\mathrm{Pb}$ in edible fish of tilapia and barbus fish were observed at both sites which exceeded the recommended limit of FAO/WHO. The high accumulation of heavy metal concentration might be caused by the closeness of the site to the highway and anthropogenic source like irrigation activities around the lake. Even though heavy metal concentrations in water were very low or negligible, the levels in tissues of fish species were relatively high. The potential sources of these heavy metals may be through the food chain obtained from the sediments and algae in 
the aquatic system. The quantities of heavy metals in fish gill, kidney and liver measured in this study provide baseline information on concentrations and distribution of heavy metals in the two fish species (Oreochromis Niloticus and Labeobarbus intermedius) from Chamo and Abaya Rift Valley Lakes. The Chamo-Abaya Lakes may not be harmful to consumers because the observed values of heavy metals were below the permissible limits issued by $\mathrm{FAO} / \mathrm{WHO}$ for human consumption. However, $\mathrm{Pb}$ was higher than permissible limits issued by FAO/WHO so; it is a matter of concern in fish accumulation. Finally, the mean differences between the values of samples obtained in this study were evaluated by the student's paired t-test at $95 \%$ confidence level. In this study, Excel Microsoft office software was used to calculate the t-values for testing the significance differences of the heavy metal concentrations between both lakes and fish species separately.

\subsection{Recommendation}

The following suggestions are recommended in order to monitor and protect the aquatic environment, due to the anthropogenic emission increases through the time.

- This study focused on only three fish body parts (gill, kidney and liver). Hence, it is recommended to perform research works on other fish organs that have the ability to accumulate trace elements such as muscle, bone, scales, skin and intestine.

- Seasonal variation may have an influence on the level of the studied analytes both in the fish and water samples. Therefore, further research undertakings are recommended by taking seasonal variation into consideration.

- Further studies are recommended in the study area both on the fish and water samples with respect to heavy metals including mercury, arsenic and others that are not addressed in the present study.

\section{Acknowledgments}

I would like to acknowledge Ethiopian Institute of Agricultural Research Center and Kulumsa Agricultural Research Center for their financial support and Holeta Agricultural Research Center, Agricultural and Nutritional Research Laboratory for providing laboratory facilities to conduct the heavy metal analysis. Additionally, I would like appreciate my advisor Dr. Endale Teju from Haramaya University Department of Chemistry and Gamo Gofa Zone Department of Livestock and Fishery Input Supplied Main Process are greatly appreciated for their assisting me during the study.

\section{REFERENCES}

Ababu Teklemariam. (2005). Water quality monitoring in Lake Abaya and Lake Chamo Region: A research based on water resources of the Abaya-Chamo basin-South Ethiopia, PhD.Thesis, Siegen University.

Alemayehu Teshome. (2008). Environment resources and recent impacts in the Hawassa collapsed caldera, Main Ethiopian Rift. Quaternary International, 189:152-162.

APHA (American Public Health Association). (1999). American water works association, Water environment federation. Standard Methods of the Examination of Water and Wastewater, $20^{\text {th }}$ ed. New York: American Public Health Association, APHA, AWWA, and WPCF.

David, A.A. and Terry, P. (2008). Limit of blank, limit of detection and limit of quantitation. Clinical Biochemistry Review, 29: 49-52.

Elizabeth Kebede, Zinabu Gebremariam and Ahgren, H. (1994). The Ethiopian Rift Valley lakes Chemical Characteristics of a Salinity Alkalinity series. Hydrobiological Kluver Academic Publishers, Belgium, 288:1-12.

FAO (1985). Water Quality for Agriculture. Irrigation and Drainage Paper No. 29, Rev. 1. Food and Agriculture Organization of the United Nations, Rome.

FAO. (1992). Committee for inland fisheries of Africa. Report of the third session of the working party on pollution and fisheries, Accra, Ghana. FAO Fisheries Report in Rome, 471.

FDRE, MoWR. (2002). Ethiopian Guidelines specification for Drinking water quality. Federal Democratic Republic of Ethiopia, Ministry of Water Resources, Addis Ababa, Ethiopia.

Gebremariam, Z. and Pearce, J.G. (2003). Concentrations of heavy metals and related trace elements in some Ethiopian Rift-Valley Lakes and their in-flows Hydrobiological, 429:171-178.

Guevara-Riba, A., Sahuquillo, A., Rubio R. and Rauret, G. (2004). Assessment of metal mobility in dredged harbour sediments from Barcelona, Spain. Science of the Total Environment,

321: 241-255.

Harvey, D. (2000). Modern analytical chemistry, First Edition, International. Mc Graw Hill.

Javed, M. and Saeed, M. A. (2010). Growth and bioaccumulation of Iron in body organs of catla, Labeo rohita and Cirrhina mrigala during chronic exposures. International Journal of Agriculture and Biology, 12: 881886.

Kebede Nigussie, Bhagwan, S.C. and Taddese Wondimu. (2010). Correlation among trace metals in Tilapia (Oreochromis niloticus), sediment and water samples of lakes Awassa and Ziway, Ethiopia. International 
Journal Biological and Chemical Science, 4(5):1641-1656.

Kiflom Gebremedhin and Tarekegn Berhanu. (2015). Determination of some selected heavy metals in fish and water samples from Hawassa and Ziway Lakes. Science Journal of Analytical Chemistry, 3(1):10-16.

Larissa, D., Mesfin Mengesha and Elias Dadebo. (2011). Assessment of heavy metals in water samples and tissues of edible fish species from Awassa and Koka Rift Valley Lakes, Ethiopia. Journals of Environmental Monitoring Assessment, 2777-2778.

Machado, L. and Griffith, R. (2005). Quality assurance project plan and sampling analysis and assessment plan for fish tissue surveys for the State of Colorado. Fish Tissue QAPP/SAP. 1-25.

Meseret Amde, Negussie Megersa, Abi Taddesse and Tesfa Bedassa. (2013). Determination of the levels of selected metals in seeds, flowers and fruits of medicinal plants used for tapeworm treatment in Ethiopia. Toxicological and Environmental Chemistry, 95(1): 82-100.

Mozaffarian, D. and Eric, B. (2006). Fish intake, contaminants, and human health: Evaluating the risks and the benefits. Journal of American Medical Association, 296:1885-1900.

Mwangi, J.M. (2013). Determination of concentration of selected heavy metals inTilapia Fish, Sediments and Water from Mbagathi and Ruiru AthiRiver Tributaries, Kenya.MSc thesis, Kenyatta University, Kenya.

Nord, L. G., Adams, C.D., Wixson, B.G., Loftin, K.A. and Huang, Y. (2004). Lead, Zinc, Copper and Cadmium in fish and sediments from the big river creek of Missouri's old lead belt. Environmental Geochemical Health, 26: 37-49.

USEPA (United State Environmental Protection Agency). (2011). Drinking water quality, Heavy metals, Maximum admissible limit, 3:105-121.

USFDA. (1993). Food and drug administration, guidance document for chromium in shellfish, Washington DC.

WHO (World Health Organisation). (2008). Guidelines for drinking water quality, $3^{\text {rd }}$ edition. Recommendations. World Health Organisation Press, World Health Organisation, Geneva, Switzerland, 1:1- 459.

WHO. (2004). Copper in drinking water. Background document for the development of who guidelines for drinking water quality, Geneva. 